Journal of Sustainable Development of Transport and Logistics

journal home page: http://jsdtl.sciview.net

Karpenko, O., Kovalchuk, S., Kuzmych, V., Gorpyniuk, A., \& Shevchuk, O. (2017). Current state and near-term prospects for development of the transport logistics market in Ukraine.

Journal of Sustainable Development of Transport and Logistics, 2(1), 51-60. doi:10.14254/jsdtl.2017.2-1.5.

ISSN 2520-2979

\title{
Current state and near-term prospects for development of the transport logistics market in Ukraine
}

\section{Olena Karpenko *, Svitlana Kovalchuk **, Valentyna Kuzmych ***, Andriy Gorpyniuk ****, Oksana Shevchuk $* * * * *$}

* National Transport University,

1, M. Omelianovycha-Pavlenka Str., Kyiv, Ukraine 01010

e-mail: tanitriel@ukr.net

PhD, Assoc. Prof., Department of Transport Law and Logistics

** National Transport University,

1, M. Omelianovycha-Pavlenka Str., Kyiv, Ukraine 01010

e-mail: swettla@ukr.net

Senior Lecturer, Department of Transport Law and Logistics

*** State Enterprise "State Road Transport Research Institute",

57 Peremohy Ave, Kyiv, 03113, Ukraine

e-mail: vkuzmich@insat.org.ua

Department of Scientific and Methodological Support Of Training and Staff Development of Road Transport

**** State Enterprise "State Road Transport Research Institute",

57 Peremohy Ave, Kyiv, 03113, Ukraine

Deputy Director for Science

***** Ternopil Ivan Pul'uj National Technical University,

56, Ruska str., 46001 Ternopil, Ukraine

e-mail: oksana_shevchuk84@ukr.net

PhD, Senior Lecturer, Department of Transport Technology

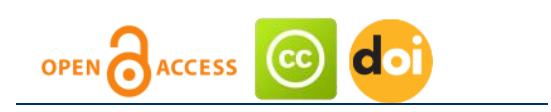

\section{Article history:}

Received: April, 2017

1st Revision: April, 2017

Accepted: May, 2017

\section{DOI:}

10.14254/jsdtl.2017.2-1.5

\begin{abstract}
The article has studied the current state of the transport services market in Ukraine, characterized features of the favorable geopolitical position of the country, identified segments of the market of transport and logistics services in Ukraine, made an analysis of the dynamics of freight transportation by land transport, determined its capacity in money terms and calculated the component share of this type of activity in the country's GDP.
\end{abstract}

Keywords: transport services, road transport, rail transport, air transport, water transport.

Corresponding author: Olena Karpenko

E-mail: tanitriel@ukr.net

This open access article is distributed under a Creative Commons Attribution (CC-BY) 4.0 license. 


\section{Introduction}

Due to the negative events in the social and political system of the country, the logistics market of Ukraine, as well as the whole country, is going through hard times. However, many market experts believe that the Ukrainian logistics has significant potential and will soon come out of the crisis phase. The main factor is the "favorable" geostrategic position of Ukraine. The study was conducted using the indicators of the whole territory of Ukraine except for the specific zones (specific zones - ATO and Crimea, since 2010 the recalculation of the Ministry of Statistics of Ukraine).

\section{The purpose of the study}

Bescribe the structure of the market of transport logistics services in Ukraine, identify the main segments of the market and determine the key market players in individual segments.

\section{Strategic position and features of the economy of Ukraine}

Ukraine has an advantageous geographical and geopolitical position, being located at the crossroads of the most important directions of the world trade and short transport routes in the Eurasian region. A number of international transport corridors with a total length of more than 5,000 km pass through the country.

New strategic prospects are created between Ukraine and the EU, and, at the same time, there is a need for significant investments for the integration of the national transport system into the transEuropean space.

By the length of the transport corridors, Ukraine is the largest European country with a large transit potential.

The transport network of Ukraine consists of:

22 thousand $\mathrm{km}$ of railway lines;

170 thousand $\mathrm{km}$ of motor roads;

2,2 thousand $\mathrm{km}$ of navigable waterways;

13 seaports, 4 fishing ports and 11 river terminals;

21 airports ( 2 - state property, 14 - municipal property, 5 - other forms of property).

The implementation of the Transport Strategy for the period until 2020 will allow creating favorable conditions for ensuring the investment attractiveness of the transport industry, developing public and private partnership, attracting investors to improve the state of Ukraine's transport infrastructure (Ministry of Infrastructure of Ukraine, 2017).

The priority areas for investment in the basic sectors of Ukraine's infrastructure:

Railway sector:

- creation of a network of interconnected logistics centers and multi-modal terminals in the largest transport hubs and checkpoints across the state border of Ukraine and EU countries;

- purchase of freight cars and operation of the freight rolling stock.

Motor road sector:

- construction of new motor roads on concession terms and the mechanism of public and private partnership;

- development, implementation and application of the national transport model in the planning and realization of the transport infrastructure development strategy;

- management of motor roads on the basis of geoinformation technologies.

Marine and river transport sectors:

- construction of new and deepening of existing waterways and water areas of seaports for the unimpeded passage of large deadweight vessels;

- construction and use of river berths, locks, dredging operations;

- modernization and creation of port infrastructure facilities on the basis of long-term lease contracts, concession, public and private partnership, joint activity contracts and other investment contracts; 
- creation and implementation of energy saving technologies on the sea transport, introduction of installations for manufacturing alternative types of fuel;

-navigation support for shipping on inland waterways and operational technological communications.

\section{Aviation sector:}

- development of the system of existing airports, runways at the aerodromes and their infrastructure;

- transfer of ownership and usage rights of airport property to concession;

-renewal of the aircraft fleet.

The leaders among investors in Ukraine's economy are: Cyprus, Germany, the Netherlands.

The index of investment attractiveness of Ukraine has grown compared to the last year. This was reported by the Communications Department of the European Business Association, which conducted another survey among top managers of its member companies and learned about the sentiments of foreign and domestic investors in 2016. So, the Index of investment attractiveness was 2.88 points out of 5 possible. This is 0.31 points greater than in the previous year. Moreover, the Index almost approached the neutral plane and became the highest for the last 4 years (EuroRating. Rating agency, 2016; Karpenko, Kovalchuk, Vovk, Hyryla, \& Shevchuk, 2016; Popovych, Shyriaieva, \& Selivanova, 2016).

The active change of Ukraine's geopolitical course towards Europe should facilitate the establishment of economic ties and access to Western capital.

The investment policy of the state can be aimed at creating the conditions for the active development of the following areas of investing in the real sector of the economy:

- energy saving technologies and alternative energy;

- raw materials companies of Ukraine associated with the extraction and primary processing of natural resources;

- enterprises of the agroindustrial complex;

- enterprises of the transport industry;

- new technological and IT projects;

- real estate sector, where today sales are carried out with a large discount.

\section{Structure of the Transport Logistics Market in Ukraine}

The market of transport and logistics services is an important component of the Ukrainian economy. It is logistics that is responsible for the optimal delivery of products from the producer to the consumer, and without the functioning of logistics structures, any activity becomes practically impossible.

Using the inductive approach, we will analyze the dynamics of development of each segment of the transport and logistics market in Ukraine and summarize it by establishing the share of income from this type of activity in the country's total gross domestic income.

In recent years, the official statistics (State Service of Statistics of Ukraine, 2017) has been keeping track of the transport market in the following sectors: transport (road, rail, water, air and pipeline); storage facilities; courier and postal activities. Since this analysis is focused on freight transportation, the primary task for the authors was to identify the share of transport services in the country's gross product. In addition, the research does not take into account some specific modes of transport, such as pipelines.

Thus, the study provides an analysis of the dynamics and development of the following sectors of the transport services market (Figure 1). 


\section{Transport Logistics of Ukraine}

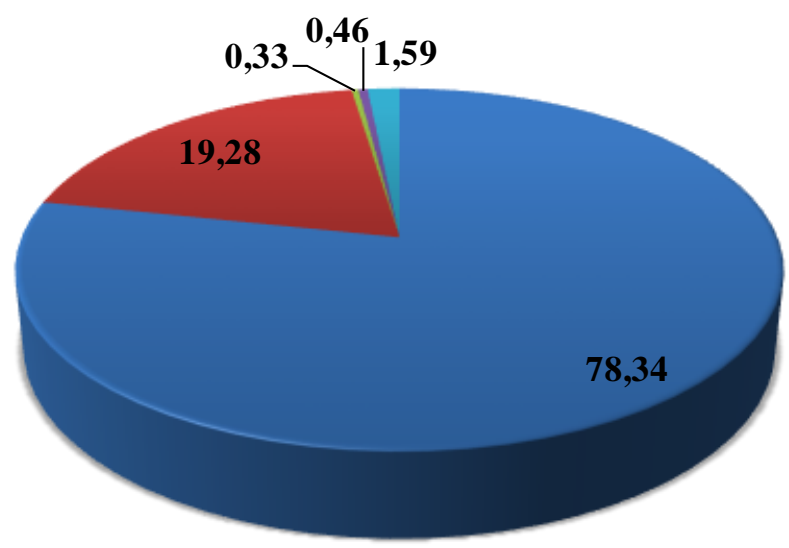

$\square$ Road freight transportation

- Rail freight transportation

$\square$ Sea freight transportation

River freight transportation

$\square$ Air freight transportation

Fig. 1. Structure of the market of transport and logistics services in 2016

As can be seen from the chart, most of the volume of freight transportation falls on the land transport $-97 \%$, and the remaining $3 \%$ are distributed between water and air transport. To identify the development trend of the transport logistics market, the authors have analyzed statistics for 10 years.

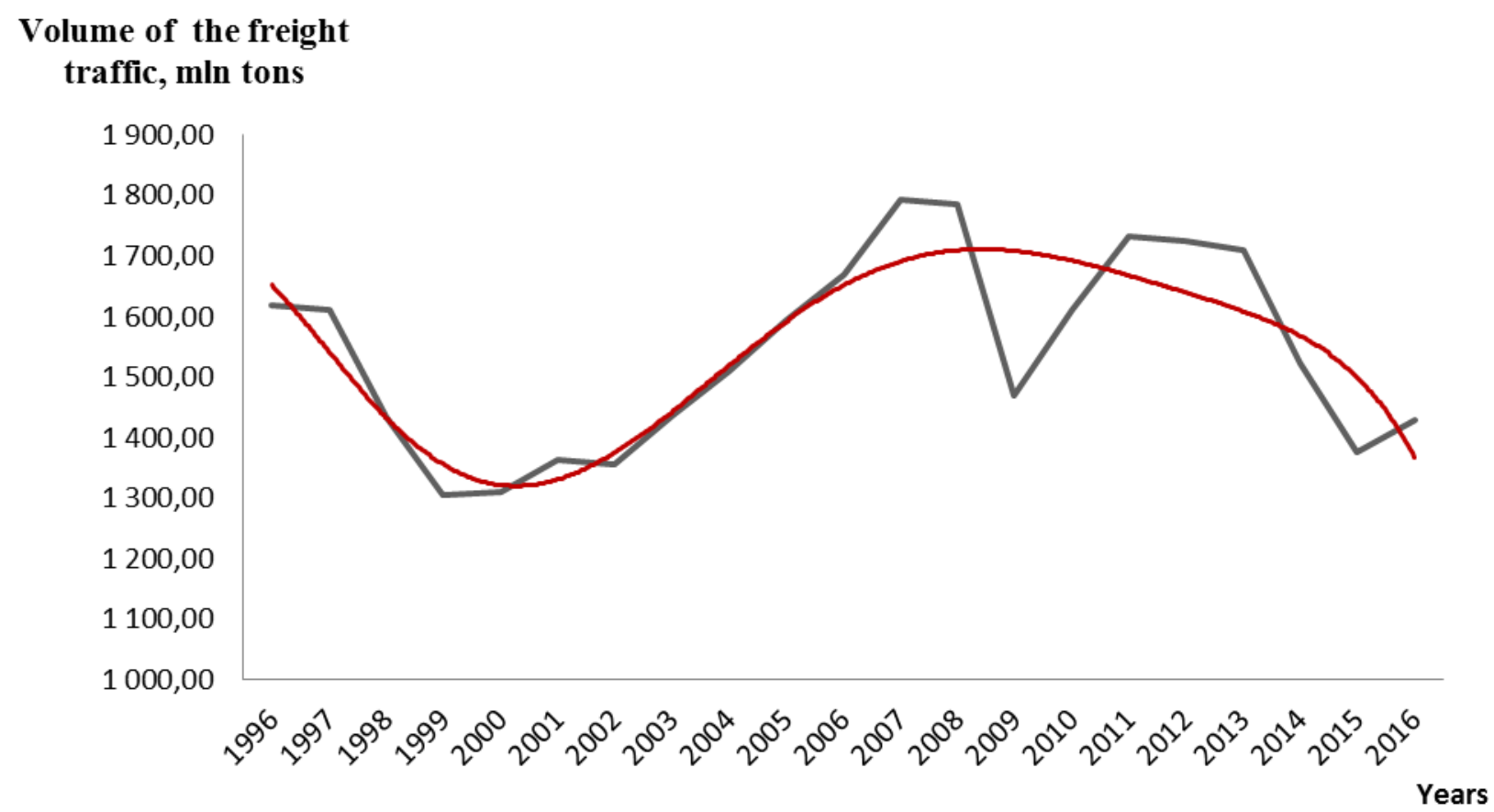

Fig. 2. Dynamics of the volume of freight traffic for 10 years

Based on the graphical analysis, it is possible to note the phase of decreasing the trend in the volumes of freight transportation in recent years. This was affected by several factors: economic crisis; destabilization of the political situation; loss of domestic and foreign markets.

Since the transport market in Ukraine is not sufficiently developed to allow the full European integration at this stage of its innovative potential, we can talk about the closeness and specificity of this market. For the transport market of Ukraine, the small cycles of development of this industry are specific. 
That is, this industry undergoes "peaks" and "falls" every 3 to 5 years, but if the representatives managers of this industry would suddenly want to realize global goals and compete with European companies, they could shift into a long period of stagnation.

Therefore, in order to form competitive advantages, it is necessary to pay proper attention to internal reserves, which are inherent not only in the transport industry, but also in the entire social and economic system of Ukraine.

First of all, let's have a look at the structure of modes of transport in Ukraine's freight traffic (see Figure 3). The characteristic feature of the freight transportation market is the prevalence of the road transport. And for the last five years, its share has increased by almost $4 \%$ in the overall structure of freight traffic. However, in 2016, the structural shares of the rail and water transport increased, which had a negligible impact on the volume of road freight transportation.

\section{Dynamics of the Structure of Freight Transportation by Water Transport, \%}

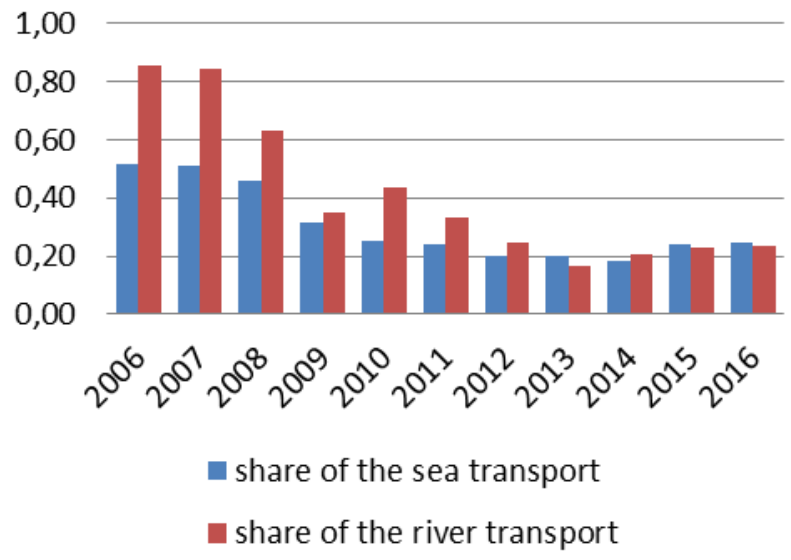

a)

\section{Dynamics of the Structure of Freight Fransportation by Land Transport, \%}

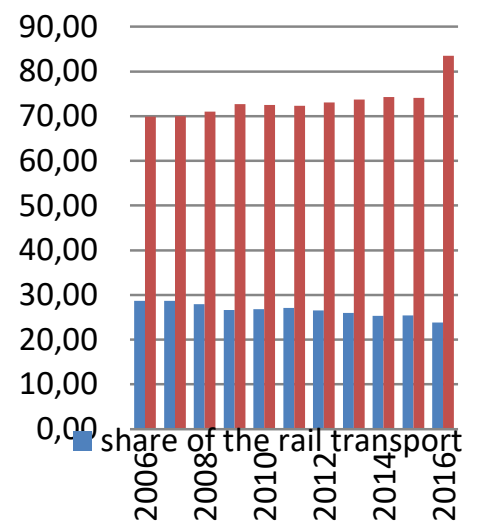

b)

Dynamics of the structure of freight transportation by air transport, \%

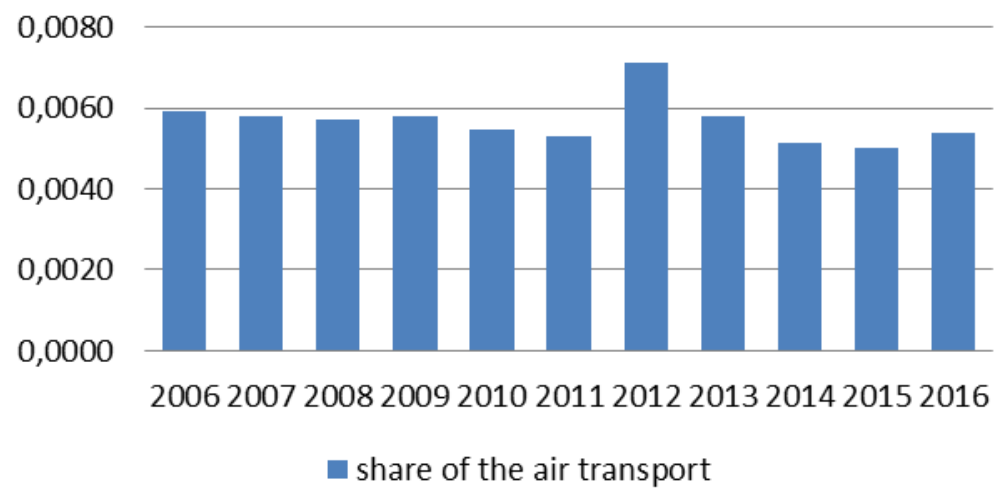

c)

Fig. 3. Dynamics of changes in the structure of freight traffic by mode of transport for 10 years

It can be seen from the histograms that the road and rail modes of transport are the most stable in dynamics and have large shares in the structure. It would be natural to assume that these two modes of transport "dictate" the rules in the logistics market. Therefore, it is worthwhile to consider the statistics on these "subsegments" in more detail.

Over the last 10 years, the level of domestic investments in the transport industry has decreased 2 times to $7 \%$ of the total level of investments in the economy. However, the level of financing road 
transportation has remained at the same level of $0.5-0.7 \%$ (UAH 1,400.00-1,600.00 mln) of the total investment in the entire economy.

Based on the official statistics, the main funds (capital) of the transport industry of Ukraine are worn out by more than $90 \%$. However, for the road transport, this indicator is not so deplorable about $60 \%$, but still, to enter the international market, the level of $40 \%$ of the vehicle renewing is evidently not sufficient. The greatest accumulation of domestic investment in road transport can be observed in Kyiv (20\%), Dnipropetrovsk (15\%) and Poltava (12\%) regions.

\section{Road Freight Transportation Market}

About 160 thousand people are employed in the road transport industry with an average salary across Ukraine of UAH 3,000.00-3,500.00. Of course, this indicator is highly averaged, since the data is official and collected through all regions. The salaries of specialists in Kyiv range from UAH 8,000 to 12,000 , and the salaries of middle managers - from UAH 4,500 to 8,000. Currently, the road transport system of Ukraine comprises of more than 9.2 million vehicles, including: 6.9 million cars; $\approx 250$ thousand buses; $\approx 1.3$ million trucks and more than 840 thousand units of motorcycle transport.

As a whole, at present, almost 56.2 thousand carriers perform entrepreneurial activity in the market of commercial transportation, and in their activity they use more than 154 thousand vehicles.

In 2016, 1,096.13 million tons of cargo were transported by road, which is $7.4 \%$ more than in 2015 (Figure 4).

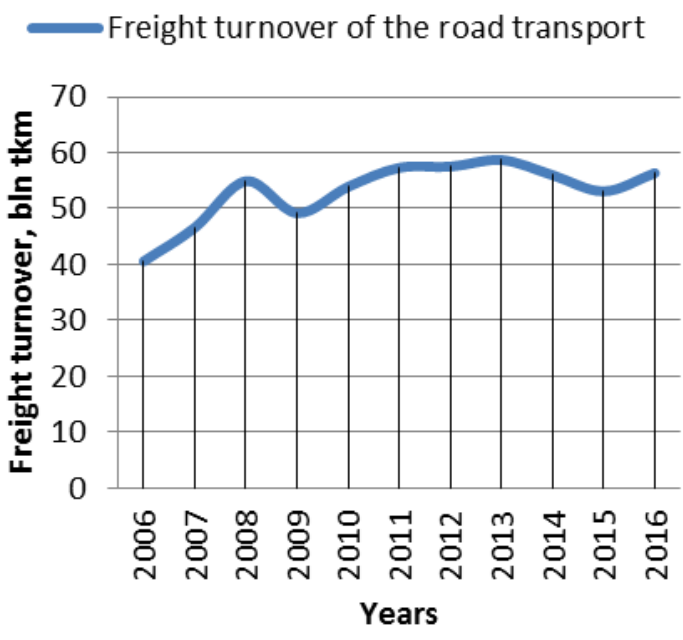

a)

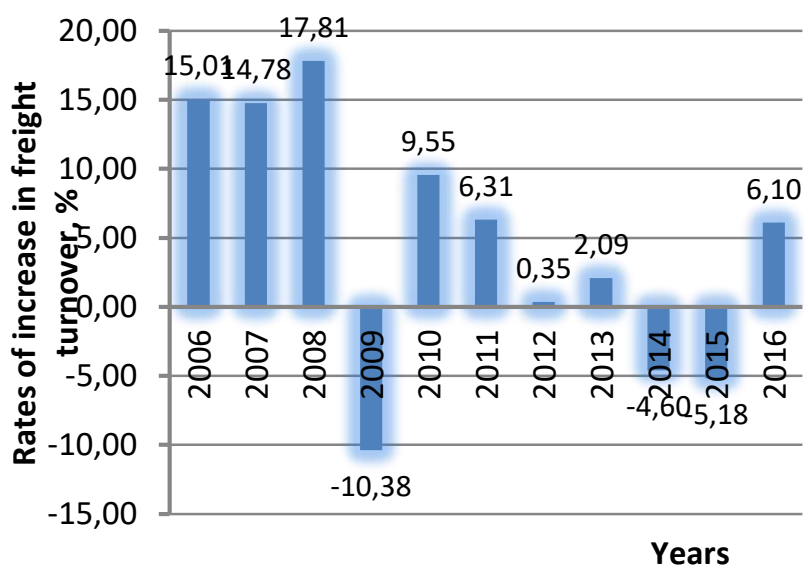

c)

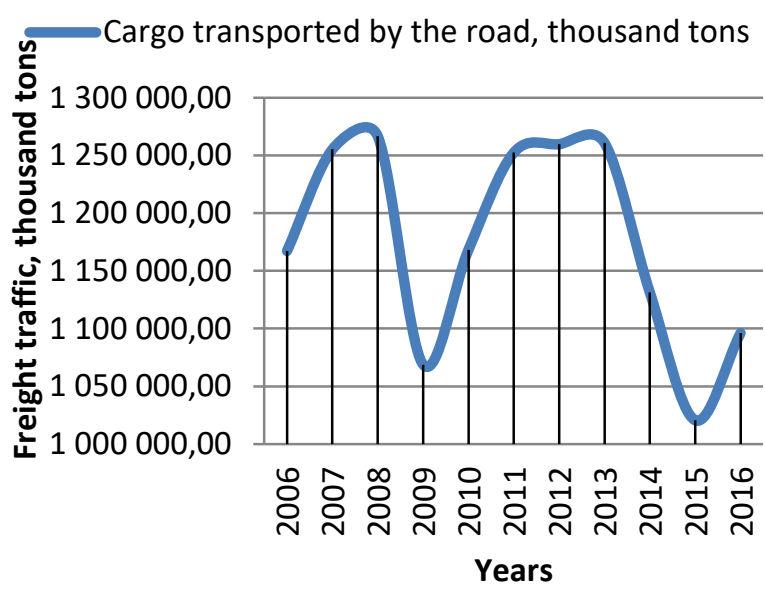

b)

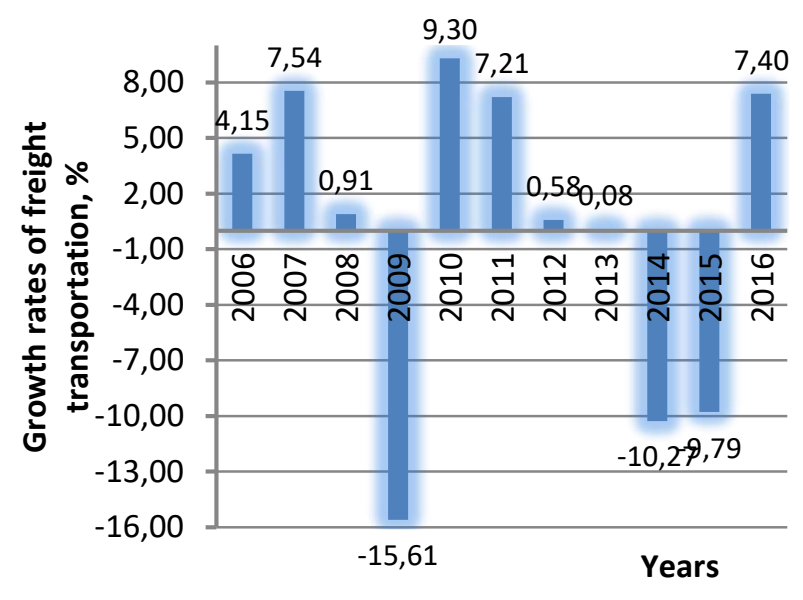

d)

Fig. 4. Dynamics of key indicators for the road freight transportation 
In 2016, both indicators changed the trend to positive. And the increase in growth rate of the freight turnover indicates that not only the transport industry, but also a large part of the social and economic system of Ukraine, has undergone the "revival",

Thus, in 2016, the volume of the domestic market of road transportation was 1,096.13 million tons or 56.34 billion tkm. If we consider these indicators in terms of regions, then the leaders are the same as for the investment: Dnipropetrovsk (28.51\%) and Poltava (15.5\%) regions. Almost 2\% of the total volume of transportation falls on Kyiv.

The average indicator of the cost of domestic freight transportation for 5 years is at the level of USD 10-11.4 per ton, and at the official rate of 2016 the price should be UAH 300.96. Accordingly, the market capacity for road freight transportation was to be UAH 329,890.89 million. This situation indicates a lack of transparency in pricing policy in the segment of road freight transportation.

\section{Rail Freight Transportation Market}

Two-thirds of the Ukrainian railway lines specialize in the transportation of goods and are equipped with modern control tools and systems for centralized traffic control and automatic block signalling.

\begin{tabular}{|l|l|}
\hline \multicolumn{1}{|c|}{ Table 1. Key Performance Indicators for the Segment of Rail Freight Transportation } \\
\hline $\begin{array}{l}\text { Operational length of the main } \\
\text { lines }\end{array}$ & $\begin{array}{l}21,640.4 \mathrm{~km}(74 \% \text { - continuous welded rails), electrified lines - } \\
9,878 \mathrm{~km}(45 \%) \text {, track gauge - 1,520 mm }\end{array}$ \\
\hline Number of railway stations & 1,447 units \\
\hline Number of railway complexes & $\begin{array}{l}118 \text { units (Among them: 18 - out-of-class, 9 - first class, 34 - } \\
\text { second class, 57 - third class) }\end{array}$ \\
\hline $\begin{array}{l}\text { Number of halt points and } \\
\text { platforms }\end{array}$ & 2,268 units \\
\hline Number of railway crossings & $\begin{array}{l}5,422 \text { units (Including those equipped with automatic crossing } \\
\text { signalling - 4,168, including crossings with a duty officer - 1,497, } \\
\text { of which 1,468 are equipped with automatic crossing signalling) }\end{array}$ \\
\hline Freight car fleet & 111,100 units \\
\hline Diesel locomotive fleet & 2,447 units \\
\hline Electric locomotive fleet & 1,547 units \\
\hline $\begin{array}{l}\text { Inventory fleet of commuter } \\
\text { trains }\end{array}$ & $\begin{array}{l}547 \text { sections of electric trains (in particular, 14 sections of rail } \\
\text { buses), of which 340 are in operation }\end{array}$ \\
\hline Inventory fleet of diesel trains & 528 sections (of which 247 are in operation) \\
\hline Number of employees & 310,000 people \\
\hline Average monthly salary & UAH 3,540 \\
\hline Freight for 2016 & 344.1 million tons \\
\hline
\end{tabular}

Resource: Ministry of Infrastructure of Ukraine, 2016.

Unfortunately, the characteristic features of the current state of activity of the rail transport in Ukraine are the critical level of the financial position and the practically worn-out rolling stock and material and technical base (about 90\%). The majority of the traction rolling stock of the Ukrainian railways was built according to the technical requirements of the $60 \mathrm{~s}$ of the last century and its normative service life has mainly almost run out. The planned volume of investments is more than UAH 3 billion and there is a hope that all this money will not sink in the abyss of improvements in passenger transportation.

It can be noted that the volumes of freight transportation by this type of transport continue to fall, while the rate of falling of the freight turnover is gradually slowing down. That is, in 2016, the level of decrease in volumes of transportation was less by $3.18 \%$ compared to the same indicator in 2015.

This suggests the possible beginning of a positive trend in the field of rail freight transportation, however, the overall position of the social and economic system is not stable yet. The volume of the 
freight transportation market in physical terms as of 2016 amounted to 344.1 million tons, which is $1.69 \%$ less than the same indicator in 2015 (Figure 5).

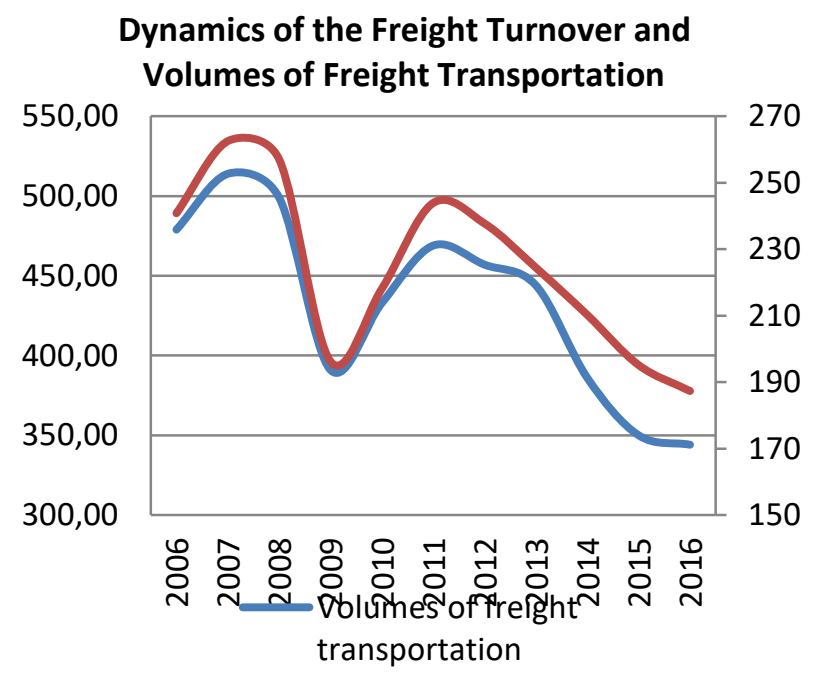

a)

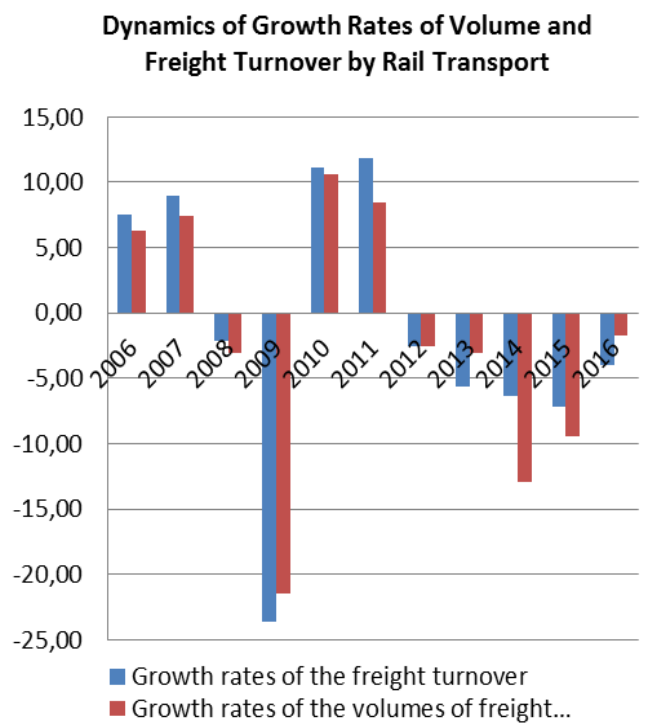

b)

Fig. 5. Dynamics of Absolute and Relative Values of the Freight Turnover and Volumes of Freight Transportation for the Rail Transport

By the regional structure, two leading railways can be marked out: Prydniprovska Railways (31\%) and Donetsk Railways (39\%), however, as for the latter, after 2013, there have been serious rates of decline in transportation volumes, which are associated not only with the general trend of decline, but also with the structural changes in the territorial division (see Figure 6).

\title{
Regional Structure of the Rail Freight Transportation
}

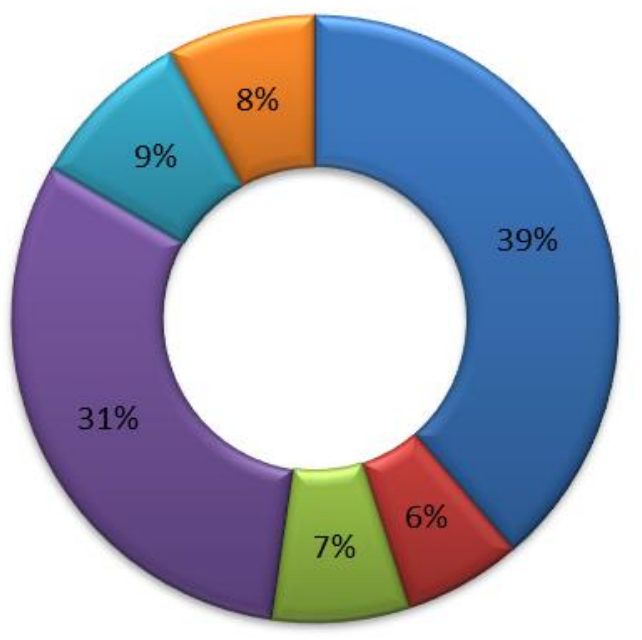

\author{
Donetsk Railways \\ - Lviv Railways \\ ๑Odessa Railways \\ ๑Cisdnieper \\ Railways \\ 口 Southwestern \\ Railways \\ 口Southern Railways
}

Fig. 6. Regional Structure of the Rail Freight Transportation

To determine the capacity of the domestic market for the rail freight transportation, we use the tariff catalog of the JSC "Ukrzaliznytsia". Since the tariff scale is very extensive, and there is a number of nuances for the tariff correction in each individual case, it is proposed to take the basic tariff for the transportation of goods by a universal car with a payload of 20 tons at a transportation distance of 100 $\mathrm{km}$. Such tariff is USD 8.51 per 1 ton of cargo, therefore the capacity of the domestic freight rail transportation market in 2016 amounted to UAH 72,025.38 million. 
Let's summarize calculations for the land transport. Considering the structures, the authors found that $97 \%$ of transport and logistics services fall on the land transport. It was logical to choose this segment as the basis for determining the main trends in the development of the market of transport and logistics services in Ukraine. Carrying out the analysis of volumes of freight transportation and price indicators, the capacity of segments in money terms for road and rail transportation was revealed. In aggregate, this indicator amounted to UAH 401,916.27 million. According to the Ministry of Finance of Ukraine (Ministry of Finance of Ukraine, 2017) in 2016, the nominal GDP amounted to UAH 2,383,182 million. Based on the figures provided, the share of freight transportation by land transport amounted to $16.87 \%$ of GDP. In the future, the authors plan to publish the next part of the studies, in which the analysis of the water and air modes of transport, as well as the related services of the transport industry, will be carried out according to the above method. Since this method of analysis is still in development, the authors of the study reserve the right to make changes in subsequent publications.

\section{Conclusion}

In the course of the study, the authors described the structure of the transport and logistics market in Ukraine. Large segments of this market were identified, including road and rail freight transportation, which in turn served as a justification for the hypothesis of a fundamental influence on the trends of the logistics market in Ukraine. Analysis of natural and cost indicators made it possible to determine the capacity of freight transportation by land transport and establish its share in the nominal GDP of the country.

\section{Appendix A. Supplementary material}

Supplementary data associated with this article can be found, in the online version, at http://jsdtl.sciview.net

\section{Funding}

The authors received no direct funding for this research.

\section{Citation information}

Karpenko, O., Kovalchuk, S., Kuzmych, V., Gorpyniuk, A., \& Shevchuk, O. (2017). Current state and near-term prospects for development of the transport logistics market in Ukraine. Journal of Sustainable Development of Transport and Logistics, 2(1), 51-60. doi:10.14254/jsdtl.2017.2-1.5.

\section{References}

EuroRating. Rating agency. (September 13, 2016). The rating of investment efficiency of the regions of Ukraine for the second quarter of 2016: the gap between leaders and outsiders is growing. Retrived from http://euro-rating.com.ua/rejting-investitsionnoj-effektivnosti-oblastejukrainy-po-itogam-vtorogo-kvartala-2016-g-razryv-mezhdu-liderami-i-autsajderami-rastet/ (Date of appeal: May 18, 2017).

Karpenko, O., Kovalchuk, S., \& Shevchuk, O. (2016). Prospects on Ukrainian logistics market orientation for international customers. Journal of Sustainable Development of Transport and Logistics, 1(1), 27-33. doi:10.14254/jsdtl.2016.1-1.5

Karpenko, O., Kovalchuk, S., Vovk, Y., Hyryla, I., \& Shevchuk, O. (2016). Problemy funktsionuvannia mekhanizmu transferu naukovykh tekhnolohii osvitnoi diialnosti $\mathrm{v}$ lohistytsi [Problems functioning of the technology transfer of scientific educational activities in logistics]. Social'noekonomičnì Problemì ì Deržava. 15(2), 114-119.

Ministry of Finance of Ukraine (March 22, 2017). Gross Domestic Product of Ukraine. Retrieved from http://index.minfin.com.ua/index/gdp/ (Date of appeal: May 18, 2017). 
Ministry of Infrastructure of Ukraine (2016). Statistical data on the Ukrainian railways. Retrieved from http://www.mtu.gov.ua/content/statistichni-dani-pro-ukrainski-zaliznici.html (Date of appeal: April 18, 2017).

Popovych, P. (2016). Analitychni tehnologiyi v zabezpechenni ekonomichnoyi efektyvnosti logistychnyh system. Herald of HNTUSG, 169, 223-225.

Popovych, P., Shevchuk, O., Matviyishyn, A., \& Lototska, V. (2016). Doslidzhennia tendentsii rozvytku rynku vantazhnykh perevezen $\mathrm{v}$ suchasnykh umovakh [Study market trends of road freight transport in modern conditions]. Journal of Zhytomyr State Technological University, 2(77), 224-228.

Popovych, P., Shyriaieva, S., \& Selivanova, N. (2016). Analysis of the interaction of participants freight forwarding system. Journal of Sustainable Development of Transport and Logistics, 1(1), 16-22. doi:10.14254/jsdtl.2016.1-1.3.

State Service of Statistics of Ukraine. (2017). Economic statistics / Economic activities / Transport. Retrieved from: http://www.ukrstat.gov.ua/operativ/menu/menu_u/tr.htm (Date of appeal: May 18, 2017).

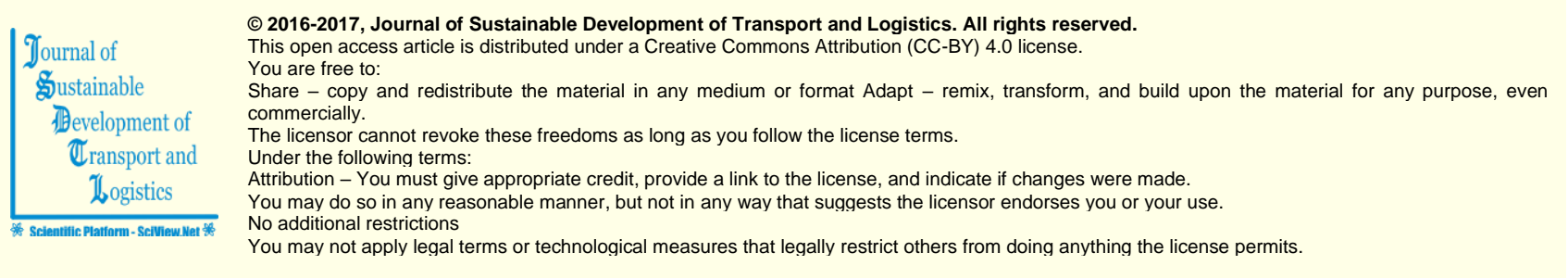

Journal of Sustainable Development of Transport and Logistics (ISSN: 2520-2979) is published by Scientific Publishing House "CSR", Poland, EU and Scientific Publishing House "SciView", Poland, EU

Publishing with JSDTL ensures:

- Immediate, universal access to your article on publication

- High visibility and discoverability via the JSDTL website

- Rapid publication

- Guaranteed legacy preservation of your article

- Discounts and waivers for authors in developing regions

Submit your manuscript to a JSDTL at http://jsdtl.sciview.net/ or submit.jsdtl@sciview.net 